\title{
Cobaltosic Oxide Catalysts for Catalytically Removing Hydrogen from Tail Chlorine
}

\author{
Tong Zhang, Ling Xue, Jianwei Xue, ${ }^{*}$ Fuxiang Li and Zhiping Lv \\ College of Chemistry and Chemical Engineering, Taiyuan University of Technology, Taiyuan 030024,China. \\ ${ }^{*}$ Corresponding author: E-mail: xuejianwei@tyut.edu.cn
}

Received: 09-19-2019

\begin{abstract}
Cobaltosic oxide has been used as catalysts in dehydrogenation for tail chlorine due to the advantages of low price and security. The $\mathrm{Co}_{3} \mathrm{O}_{4} / Z \mathrm{ZSM}-5$ was synthesized by the volume impregnation method. The catalytic dehydrogenation performance of $\mathrm{Co}_{3} \mathrm{O}_{4} / Z \mathrm{ZSM}-5$ was investigated, the catalytic reaction of hydrogen with oxygen and chlorine was carried out in a fixed-bed, and the mixed reactant gases were prepared according to the composition and content of tail chlorine in industry: $\mathrm{Cl}_{2}(65 \%-80 \%), \mathrm{N}_{2}(6-16 \%), \mathrm{O}_{2}(8 \%-10 \%)$ and $\mathrm{H}_{2}(1.5 \%-4 \%)$. The catalytic efficiency and stability of $\mathrm{Co}_{3} \mathrm{O}_{4} /$ ZSM-5 in dehydrogenation for tail chlorine were better than that of $\mathrm{Co}_{3} \mathrm{O}_{4}$. After the calcination on $300{ }^{\circ} \mathrm{C}$, the $\mathrm{Co}_{3} \mathrm{O}_{4} /$ ZSM-5 with $1 \%$ wt. $\mathrm{Co}_{3} \mathrm{O}_{4}$ shown excellent catalytic performance at $50{ }^{\circ} \mathrm{C}$, and the average conversion of hydrogen can reach up to $99.59 \%$.
\end{abstract}

Keywords: Cobaltosic oxide; $\mathrm{Co}_{3} \mathrm{O}_{4} / \mathrm{ZSM}-5$; tail-chlorine; dehydrogenation

\section{Introduction}

The chlor-alkali industry plays a very important role in the basic chemical industry owing to the critical position in the manufacture of thousands of downstream chemicals. ${ }^{1}$ Chlorine and sodium hydroxide are two major products of the chlor-alkali industry, which are the most important inorganic commodities and widely used as raw materials for other processes (handbook of chemical economics,2018). ${ }^{2}$ Due to the recent development, the production of chlor-alkali and the scale of industrial equipment have made great breakthroughs. By the end of 2016, there are more than 500 chlor alkali producers in the world. The world caustic soda production capacity is about $94.7 \mathrm{Mt}$, and the output is close to $70 \mathrm{Mt} / \mathrm{a}$. China has the largest caustic soda production capacity in the world. ${ }^{3,4}$ There are 161 caustic soda enterprises with a total output of $42.59 \mathrm{Mt}$ in China at the end of $2016 .{ }^{5}$ Based on market data in this year, the demand for caustic soda is still increasing. The by-product tail chlorine in the chlorine tail gas will inevitably become a more important issue in the industrial production of chlor-alkali. Tail chlorine comes from chlor-alkali industry, which is a process of compressed liquefaction preparation liquid chlorine enriched in chlorine gas, including chlorine gas, nitrogen, oxygen and hydrogen etc. The mixed gas may explode due to hydrogen accumulation when it is used in the downstream. The hydrogen in the mixed gas has been a great po- tential safety hazard. ${ }^{6}$ Therefore, it is very urgent to develop environment-friendly and effectively methods for the dehydrogenation in chlorine tailings.

There are four common industrial methods for dehydrogenation of tail chlorine: synthetic hydrochloric acid, absorption-desorption, lye absorption and PSA pressure swing adsorption. ${ }^{7,8}$ The synthesis of hydrochloric acid by burning hydrogen and chlorine at high temperature to produce hydrochloric acid, ${ }^{9}$ while tail chlorine is consumed. This is a mature method in industry, but at present the economic benefit of this method is too poor. Dehydrogenation with green catalysts is in line with the national energy conservation and emission reduction and green development concept, which can reduce hydrogen content and even completely dehydrogenate. In the 1950s, it was discovered that hydrogen and chlorine could be catalyzed into hydrogen chloride to remove hydrogen. Kulcsar and Geza scholars for the first time in 1957 used activated carbon as a carrier of load type catalyst under $250{ }^{\circ} \mathrm{C}$,chlorine and hydrogen for hydrogen chloride. Subsequently, ${ }^{10}$ Allen and Coolen et al.. investigated that the reaction should be controlled within a certain temperature range, otherwise the side reaction occurred at an excessively high reaction temperature. ${ }^{11,12} \mathrm{Re}-$ searchers showed that some precious metals (platinum,palladium,rhodium,etc.) and its alloys, as well as cheap manganese metals reduced the hydrogen content in tail chlorine to less than $10^{-6}$ in a certain temperature range 
(200-400 ${ }^{\circ} \mathrm{C}$ ). Pieters et al. with $\mathrm{SiO}_{2}$ carrier load $\mathrm{K}$, $\mathrm{La}$ and $\mathrm{Cu}$ chloride preparation as a catalyst, when residual hydrogen content in the best conditions of PPM level,they then used the activated alumina catalyst carrier load the precious metal Pt made around $260^{\circ} \mathrm{C}$ catalytic reaction. ${ }^{13}$

The previous studies on the dehydrogenation performance of tail chlorine have also made some progress. Zhou investigated $\mathrm{Ce} / \mathrm{Pt} / \mathrm{SiO}_{2}$ as catalyst for low-temperature catalytic tail-chlorine dehydrogenation. She found the optimal reaction condition was $1 \%$ wt. Pt loaded on $\mathrm{SiO}_{2}$ catalyst with $2 \%$ wt. of additive $\mathrm{Ce}\left(\mathrm{NO}_{3}\right)_{3}$. The total conversion rate of $\mathrm{Ce} / \mathrm{Pt} / \mathrm{SiO}_{2}$ was $92 \%$ at the reaction temperature of $60{ }^{\circ} \mathrm{C} \cdot{ }^{14}$ Later, the $\mathrm{Au}-\mathrm{Ag} / \mathrm{Al}_{2} \mathrm{O}_{3}$ bimetallic catalyst prepared by $\mathrm{Lu}$ has a hydrogen conversion rate of $94.58 \%$ with the calcination temperature of $500{ }^{\circ} \mathrm{C}$ under the reaction temperature of $100{ }^{\circ} \mathrm{C} .{ }^{15}$ Subsequently, Wang et al.continued to developed the catalytic effects of $\mathrm{Pd} /$ $\mathrm{Al}_{2} \mathrm{O}_{3}$ and $\mathrm{Pd} / \mathrm{SiO}_{2}$, a $97 \%$ conversion of hydrogen achieved at $60{ }^{\circ} \mathrm{C}$. The noble metal catalyst not only reduced the reaction temperature, but also greatly improved the dehydrogenation rate, but they were not only expensive, but also had a low repetition rate, which is not suitable for industrial use. ${ }^{16}$ Therefore, Chen selected to use cheap metal. $\mathrm{CuO} / \mathrm{Al}_{2} \mathrm{O}_{3}$ calcined at $550{ }^{\circ} \mathrm{C}$ was used as a catalyst with a load content of $8 \%$ wt., It's average hydrogen conversion rate catalyzed at $110^{\circ} \mathrm{C}$ was $90.03 \%$. However, the catalyst with poor stability made the conversion rate decrease rapidly. ${ }^{17}$ Liu employed cheap metal $\mathrm{Fe}_{2} \mathrm{O}_{3} / \mathrm{Al}_{2} \mathrm{O}_{3}$ to obtain the superior catalytic performance with conversion rate of hydrogen of $84.11 \%$ at reaction temperature of $70{ }^{\circ} \mathrm{C}$ and calcination temperature of $500{ }^{\circ} \mathrm{C}$. Among tthat route, it was found that production of the ferric chloride of by products. This method can not only achieve dehydrogenation effect, but also prepare ferric chloride products. ${ }^{18}$

In this article, the cobalt-based catalyst was prepared by using high specific surface area ZSM- 5 as supporter. ZSM-5 zeolite has lot of advantages such as thermal stability, unique channel structure, large surface, acidity and shape-selectivity. As is known to us, it has been proverbially used as the support in various moderate acid-catalyzed reactions. ${ }^{19}$ This method for catalyst preparation has low energy consumption and simple process, While using this catalyst, safety problem of tail chlorine can be solved fundamentally, and secondary pollution to the environment will not happen.

\section{Experiment}

\section{1. Catalyst Preparation}

ZSM-5-supported $\mathrm{Co}_{3} \mathrm{O}_{4}$ catalysts was synthesized by using the volume impregnation method with $\mathrm{Co}\left(\mathrm{NO}_{3}\right)_{2} \cdot 6 \mathrm{H}_{2} \mathrm{O}$. A series of cobalt nitrate aqueous solutions with different mass fractions were prepared, and then the cobalt nitrate aqueous solution with the same volume was soaked for $24 \mathrm{~h}$ with $1 \mathrm{~g}$ ZSM- 5 at room temperature. After that, it was dried in a oven at $100{ }^{\circ} \mathrm{C}$ for $12 \mathrm{~h}$, and finally calcined for 6 hours at $300{ }^{\circ} \mathrm{C}-700{ }^{\circ} \mathrm{C} .{ }^{20}$ Then put it into the sample bag and label it for later use.

\section{2. Catalyst Characterization}

After reaction, the product mixture content detection of $1 \mathrm{ml}$ was quantitatively analyzed by gc- 900 gas chromatograph with a $3 \mathrm{~mm}^{\star} 3 \mathrm{~m} 5 \mathrm{~A}$ molecular sieve stainless steel packed column and a thermal conductivity cell detector. Argon was used as a carrier gas with a gas velocity of $15 \mathrm{ml} / \mathrm{min}(0.05 \mathrm{mpa})$. The temperature of vaporization chamber and detector were $100{ }^{\circ} \mathrm{C}$ accompanied by column temperature of $55^{\circ} \mathrm{C}$ and bridge current of $60 \mathrm{~mA}$. The X-ray diffraction (XRD) patterns of the catalyst were obtained by using a diffractometer XRD-6000), operating at $40 \mathrm{kv}$ and $30 \mathrm{ma}$ with $\mathrm{Cu}$-ka palladium and nickel filtering. Scanning electron microscope (SEM) pattern of the catalysts was taken by JSM-6300 of Nicocet company in Japan, which was conducted to investigate the morphology of samples with treating by gold spray. Element analysis (EDS) was used to assist in the analysis of the SEM electron micrograph. The $\mathrm{N}_{2}$ adsorption-desorption was employed to measure the surface area and pore volume by using a NOVA 2000e analyzer.

\section{3. Experimental Steps}

The experimental procedure is as follows: Firstly, $0.5 \mathrm{~g}$ catalyst was put into the fixed-bed reactor system as shown

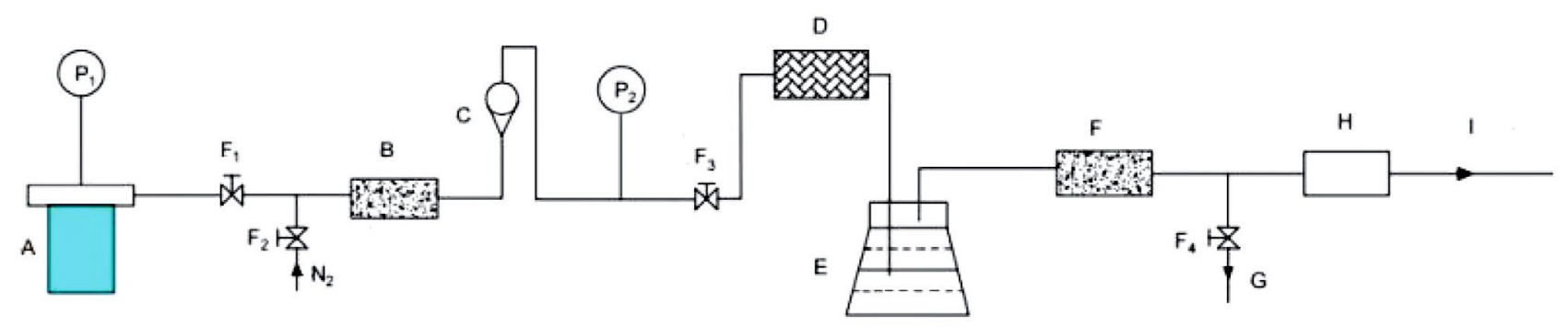

Figure 1. The device for removing hydrogen from the tail chlorine A Gas tank; B. Calcium chloride dryer; C. Flowmeter; D. Quartz tube reactor; E. Sodium hydroxide solution; F. Calcium oxide dryer; G. Sampling device; H. Tail gas treatment; I. Tail gas outlet; $\mathrm{F}_{1}, \mathrm{~F}_{2}, \mathrm{~F}_{3}, \mathrm{~F}_{4}$. The valve; $\mathrm{P}_{1}, \mathrm{P}_{2}$. Vacuum manometer 
in Figure 1, and the whole pipeline was purged with nitrogen to remove water. Then, the tail chlorine mixture simulated according to the composition of industrial tail chlorine $\left(3.97 \% \mathrm{H}_{2}, 9.93 \% \mathrm{O}_{2}, 13.25 \% \mathrm{~N}_{2}\right.$ and $72.85 \% \mathrm{Cl}_{2}$ ) was put into the reactor. ${ }^{21,22}$ The hydrogen content of the tail chlorine after dehydrogenation was analyzed by gas chromatography and the conversion rate of hydrogen was calculated to detect its catalysis and properties of chemical agents.

\section{4. Calculation Method of Hydrogen Conversion}

The above figures show the changes of gas flow rate before and after the reaction, respectively. The conversion rate of each reactant was defined as eq 1 ,

$$
\operatorname{Con}_{\mathrm{O}_{2}}=\left(d_{0} \times c_{0 O_{2}}-d_{1} \times c_{1 O_{2}}\right) /\left(d_{0} \times c_{0 O_{2}}\right)
$$

It would found that hydrogen - oxygen reaction and hydrogen - chlorine are involved in the reaction. The selectivity of hydrogen - oxygen is calculated as eq 8 ,

$$
\begin{aligned}
\operatorname{Sel}_{\left(H_{2}-H_{2} O\right)} & =2 \times\left(d_{0} \times c_{0 O_{2}}-d_{1} \times c_{1 O_{2}}\right) /\left(d_{0} \times c_{0 H_{2}}-d_{1} \times c_{1 H_{2}}\right) \\
& =2 \times\left(c_{0 O_{2}}-c_{1 O_{2}}\right) /\left(c_{0_{H_{2}}}-c_{1 H_{2}}\right)
\end{aligned}
$$

the selectivity of hydrogen - chlorine, as a consequence, can be reckoned as eq 9 ,

$$
\begin{aligned}
\operatorname{Sel}_{\left(\mathrm{H}_{2}-\mathrm{HCl}\right)} & =1-\mathrm{Sel}_{\left(\mathrm{H}_{2}-\mathrm{H}_{2} \mathrm{O}\right)} \\
& =1-2 \times\left(c_{0 \mathrm{O}_{2}}-c_{1 \mathrm{O}_{2}}\right) /\left(c_{\mathrm{H}_{2}}-c_{1 \mathrm{H}_{2}}\right)
\end{aligned}
$$

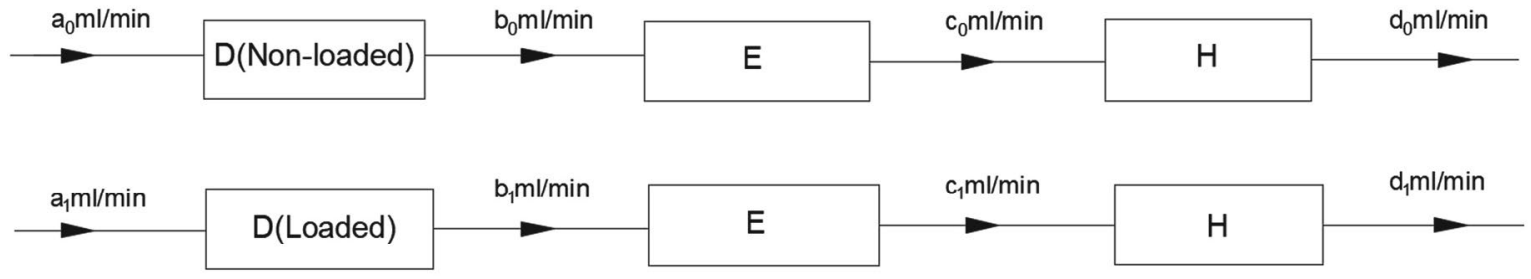

Figure 2. Calculation of hydrogen content in a gas mixture

$$
\text { Con }=\left(d_{0} \times c_{0}-d_{1} \times c_{1}\right) /\left(d_{0} \times c_{0}\right)
$$

Where the initial velocity is described as $\mathrm{a}_{0}$ and $\mathrm{a}_{1}$. After reaction, it's $b_{0}$ and $b_{1} \cdot c_{0}$ and $c_{1}$ are exhibited with the absorption of chlorine and $\mathrm{d}_{0}$ and $\mathrm{d}_{1}$ are the velocity after reaction with sodium carbonate. Hence, the hydrogen conversion rate and oxygen conversion rate are set as eq 2 and eq 3 severally,

$$
\begin{aligned}
& \operatorname{Con}_{\mathrm{H}_{2}}=\left(d_{0} \times c_{0 \mathrm{H}_{2}}-d_{1} \times c_{1 \mathrm{H}_{2}}\right) /\left(d_{0} \times c_{0 \mathrm{H}_{2}}\right) \\
& \operatorname{Con}_{\mathrm{O}_{2}}=\left(d_{0} \times c_{0 \mathrm{O}_{2}}-d_{1} \times c_{1 \mathrm{O}_{2}}\right) /\left(d_{0} \times c_{0 \mathrm{O}_{2}}\right)
\end{aligned}
$$

Where $c_{0 \mathrm{H}_{2}}, c_{0 \mathrm{O}_{2}}$ and $c_{0 \mathrm{~N}_{2}}$ are respectively the volume concentrations of hydrogen, oxygen, and nitrogen in the mixture before the reaction, while $c_{1 H_{2}}, c_{1 O_{2}}$ and $c_{1 N_{2}}$ are after the reaction. Since the hydrogen is only about $4 \%$ and the proportion of chlorine gas is higher, it is reasonable to assume that the gas velocity is basically unchanged after the reaction. As suggested by eq 4 and eq 5 ,

$$
\begin{aligned}
& \mathrm{a}_{0}=\mathrm{a}_{1}=\mathrm{b}_{0} \approx \mathrm{b}_{1} \\
& \mathrm{c}_{0}=\mathrm{d}_{0} \approx \mathrm{c}_{1}=\mathrm{d}_{1}
\end{aligned}
$$

Eq 6 and eq 7 can be obtained by substituting the above formula into the conversion rate formula,

$$
\mathrm{Con}_{\mathrm{H}_{2}}=\left(c_{0 \mathrm{H}_{2}}-c_{1 \mathrm{H}_{2}}\right) / c_{0 \mathrm{H}_{2}}
$$

\section{Results and Discussion 3. 1. X-ray Diffraction}

As suggested by Figure 3, the characteristic diffraction peaks of $\mathrm{Co}_{3} \mathrm{O}_{4}$ were obtained at $19.0^{\circ}, 31.3^{\circ}, 36.9^{\circ}$, $38.6^{\circ}, 44.8^{\circ}, 55.7^{\circ}, 59.4^{\circ}$, and $65.3^{\circ}$. After the reaction, a weak characteristic diffraction peaks of catalyst presented at $75.8^{\circ}$, which indicated that a trace of cobalt chloride was generated in the catalytic reaction process.

The XRD analysis of $\mathrm{Co}_{3} \mathrm{O}_{4} / \mathrm{ZSM}-5$ at different reaction temperature was presented in Figure 4, which was

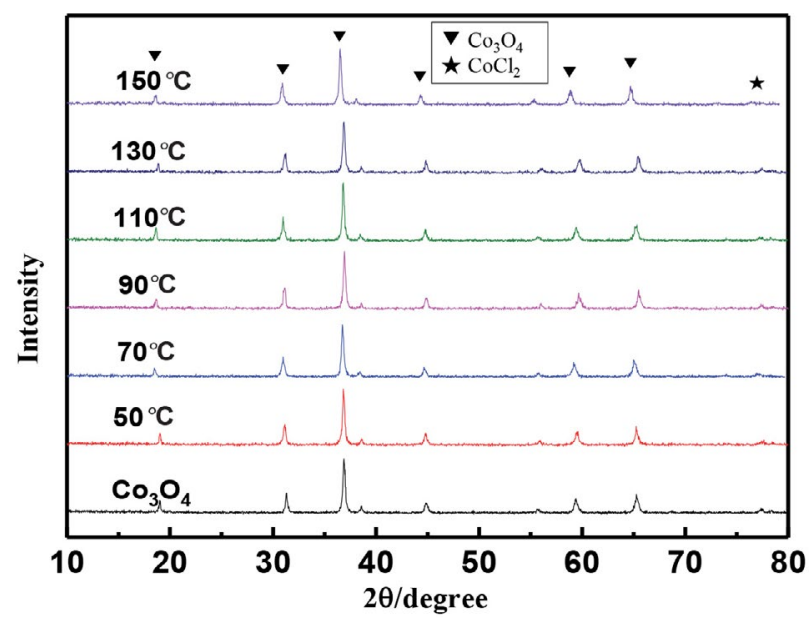

Figure 3. $\mathrm{XRD}$ patterns of $\mathrm{Co}_{3} \mathrm{O}_{4}$ at different reaction temperature 


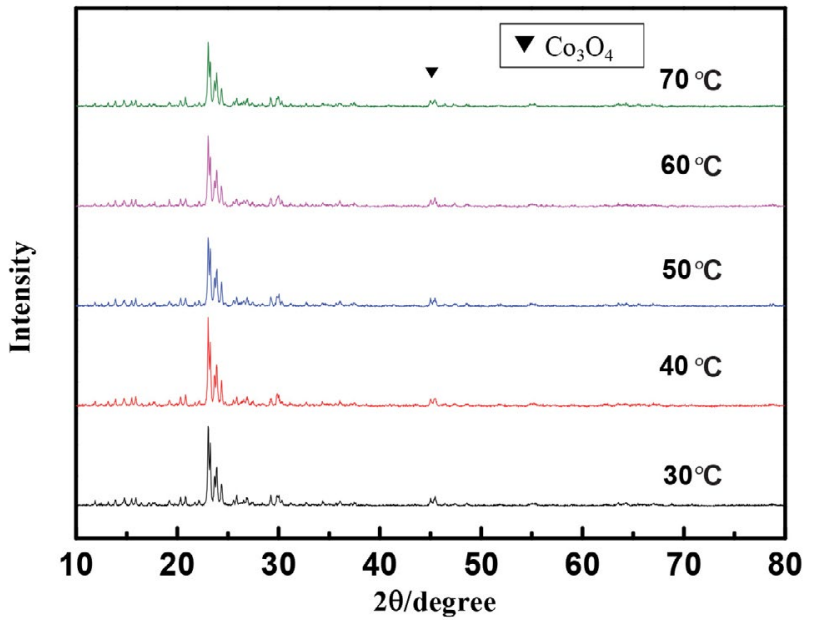

Figure 4. XRD patterns of $\mathrm{Co}_{3} \mathrm{O}_{4} / Z S M-5$ at different reaction temperature



Figure 5. XRD patterns of $\mathrm{Co}_{3} \mathrm{O}_{4} / \mathrm{ZSM}-5$ at different calcination temperature

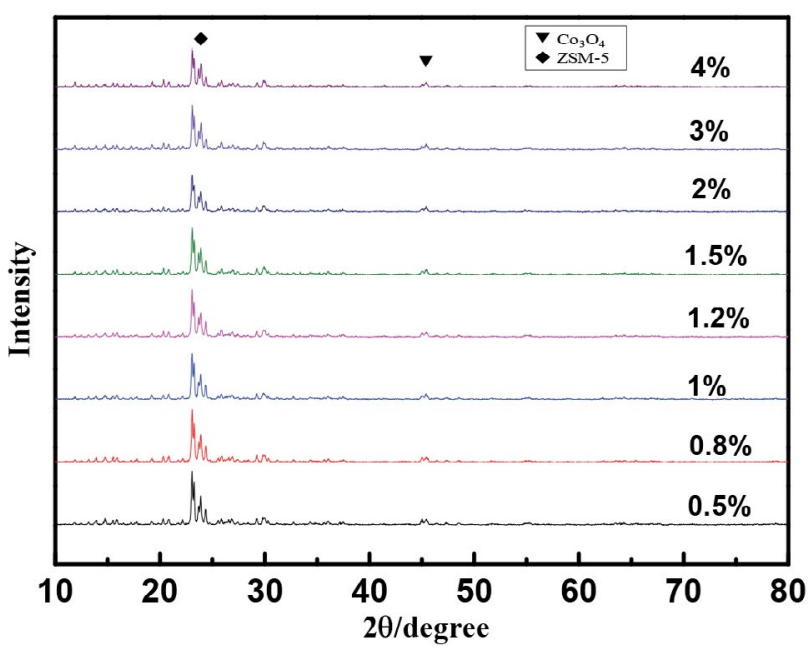

Figure 6. The XRD patterns of $\mathrm{Co}_{3} \mathrm{O}_{4} / \mathrm{ZSM}-5$ at different loading loaded with $1 \%$ wt. and calcined at $600{ }^{\circ} \mathrm{C}$. Compared with unloaded cobaltosic oxide, the characteristic diffraction peak of cobaltosic oxide also presented at about $45^{\circ}$ in Figure 4, exhibiting that the presence of cobalt element in the form of $\mathrm{Co}_{3} \mathrm{O}_{4}$. It was assumed that the catalyst had good stability due to there is no diffraction peak of cobalt chloride. Maybe It's because the generation of cobalt chloride rarely not detected. The characteristic peak of $\mathrm{Co}_{3} \mathrm{O}_{4}$ was found in different load, and the intensity of the peak increased with the increase of load.

The XRD analysis of $\mathrm{Co}_{3} \mathrm{O}_{4} / \mathrm{ZSM}-5$ at different calcination temperature was set as Figure 5, which are loaded with $1 \% w t$. and participated in reaction at $50{ }^{\circ} \mathrm{C}$. From Figure 5 , it can be seen that the characteristic diffraction peak corresponding to cobaltosic oxide all presented at about $45^{\circ}$ at different calcination temperature. However, the strength of peak decreased indistinctly with increase of calcination temperature, which illustrated that the enhanced temperature was unfavorable to the crystallization of cobaltosic oxide. The consecutive high-intensity peaks of ZSM- 5 having a specific $2 \theta$ value of $23^{\circ}-25^{\circ}$ were commonly found in each catalyst sample, indicating that after calcination as well as reaction ZSM-5 structure clearly preserved.

For various $\mathrm{Co}_{3} \mathrm{O}_{4}$ loadings, the $\mathrm{XRD}$ analysis of catalysts were set as Figure 6, which were calcined at $300{ }^{\circ} \mathrm{C}$ and participated in reaction at $50{ }^{\circ} \mathrm{C}$. As suggested by Figure 6 , all the catalysts revealed characteristic peaks of ZSM- 5 crystal in the ranges of $2 \theta=23 \sim 25$ which were evident that the crystalline framework of the ZSM-5 was retained after the loading in all the catalysts. ${ }^{23}$ With increasing loading of $\mathrm{Co}_{3} \mathrm{O}_{4} / \mathrm{ZSM}-5$, the characteristic diffraction peak of ZSM- 5 became weaker. This is due to the introduction of $\mathrm{Co}_{3} \mathrm{O}_{4}$, which leads to the decrease of the order degree of the molecular sieve structure, indicating that some cobalt ions are exchanged to the internal control surface of the molecular sieve. ${ }^{24}$

\section{2. SEM Analysis}

Figure 7 shows the SEM images of $\mathrm{Co}_{3} \mathrm{O}_{4}$ samples before and after catalytic reaction. As can be seen from figure $a$ and $b$, cobaltosic oxide particles with hexagonal structure and smooth surface, which was arranged neatly, loose and fine before reaction. In contrast to figure a and c, the phenomenon of agglomerating occurred in the catalyst after the reaction. With the destruction of some hexagonal structure of particles, the particle size became larger, and there seemed to be traces of corrosion of hydrogen chloride and water on the surface. It was performed that the SEM images of $\mathrm{Co}_{3} \mathrm{O}_{4}$ supported on ZSM-5. $\mathrm{Co}_{3} \mathrm{O}_{4}$ supported on ZSM- 5 showed irregular shape and good dispersity on the ZSM- 5 support. The distribution of samples after reaction was loose, but the overall change is not significant. 

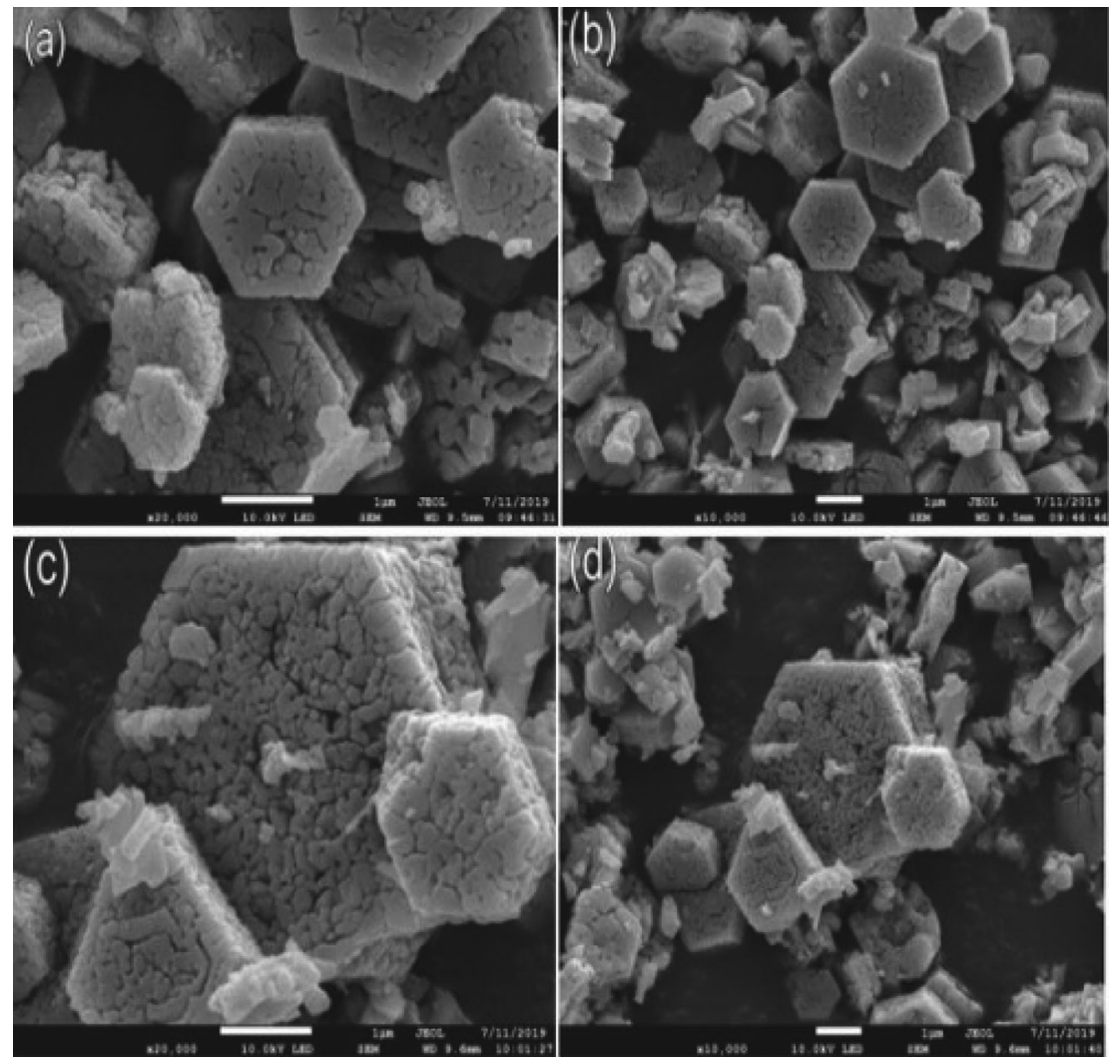

Figure 7. $\mathrm{SEM}$ of $\mathrm{Co}_{3} \mathrm{O}_{4}$ before $(\mathrm{a}, \mathrm{b})$ and after reaction(c,d)


Figure 8. SEM images of $\mathrm{Co}_{3} \mathrm{O}_{4} / \mathrm{ZSM}-5$ before $(\mathrm{a}, \mathrm{b})$ and after reaction(c,d) 


\section{3. EDS Analysis}

The analysis of EDS test results exhibited that there was no drastic change of the elements before and after the reaction, no matter cobaltosic oxide or cobaltosic oxide loaded, which can also be supported by the SEM results. The morphology of pure cobaltosic oxide changed after reaction, while the cobaltosic oxide after loading was basically the same. This further revealed that $\mathrm{Co}_{3} \mathrm{O}_{4} / \mathrm{ZSM}-5$

Table 1. Elemental analysis of $\mathrm{Co}_{3} \mathrm{O}_{4}$ catalyst

\begin{tabular}{lccc}
\hline Element & C & O & Co \\
\hline $\mathrm{Co}_{3} \mathrm{O}_{4}$ (before) $(\mathrm{w} \%)$ & 1.00 & 24.93 & 74.07 \\
$\mathrm{Co}_{3} \mathrm{O}_{4}$ (before) (at\%) & 2.87 & 53.76 & 43.37 \\
$\mathrm{Co}_{3} \mathrm{O}_{4}$ (after) (w\%) & 1.05 & 24.46 & 74.49 \\
$\mathrm{Co}_{3} \mathrm{O}_{4}$ (after) (at\%) & 3.03 & 53.09 & 43.88 \\
\hline
\end{tabular}
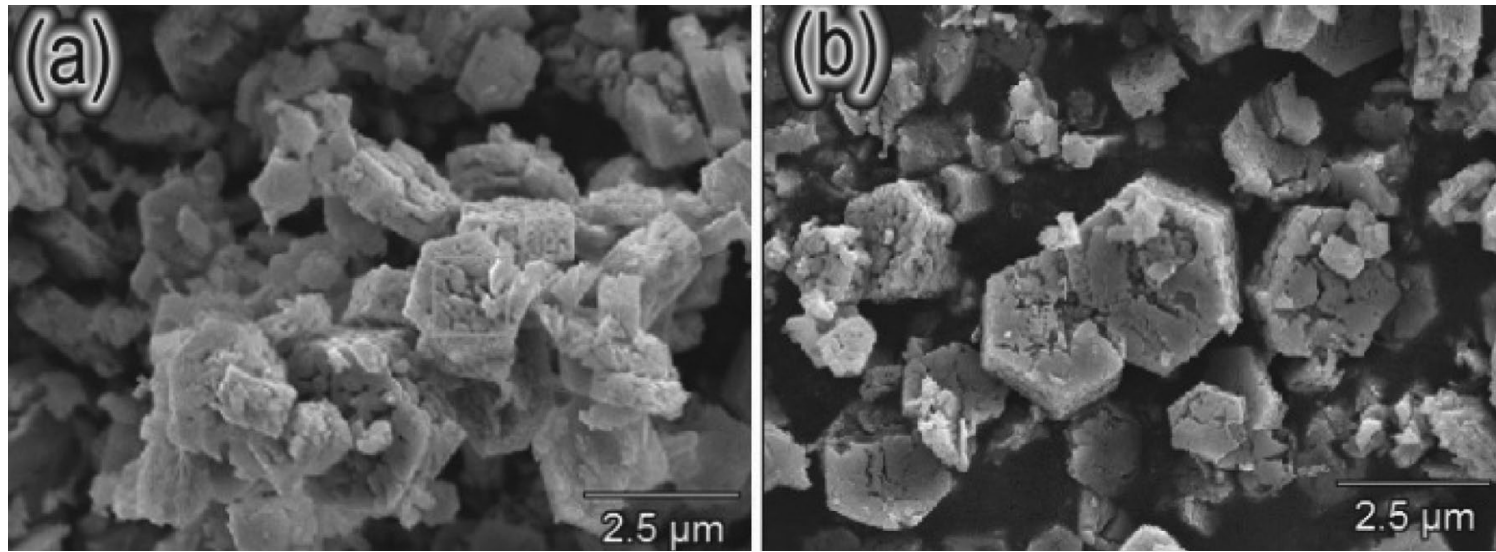

Figure 9. EDS spectra of $\mathrm{Co}_{3} \mathrm{O}_{4}$ catalyst before (a) and after (b) reaction

Table 2. Elemental analysis of $\mathrm{Co}_{3} \mathrm{O}_{4} / \mathrm{ZSM}-5$ catalyst

\begin{tabular}{lccccc}
\hline Element & C & O & Al & Si & Co \\
\hline $\mathrm{Co}_{3} \mathrm{O}_{4} /$ ZSM-5(before) (w\%) & 1.46 & 47.19 & 2.53 & 35.33 & 13.49 \\
$\mathrm{Co}_{3} \mathrm{O}_{4} /$ ZSM-5(before) (at\%) & 2.67 & 65.06 & 2.07 & 27.74 & 2.45 \\
$\mathrm{Co}_{3} \mathrm{O}_{4} / \mathrm{ZSM}$-5(after) (w\%) & 2.77 & 48.84 & 2.49 & 34.54 & 11.35 \\
$\mathrm{Co}_{3} \mathrm{O}_{4} / \mathrm{ZSM}-5$ (after) (at\%) & 4.91 & 64.99 & 1.96 & 26.18 & 1.95 \\
\hline
\end{tabular}


Figure 10. EDS spectra of $\mathrm{Co}_{3} \mathrm{O}_{4} / \mathrm{ZSM}-5$ catalyst before (a) and after (b) reaction 
made more excellent performance in terms of catalytic activity and stability.

\section{4. Nitrogen Adsorption-Desorption}

Figure 11 shows the textural properties of ZSM-5, $1 \% \mathrm{Co}_{3} \mathrm{O}_{4} / \mathrm{ZSM}-5,1 \% \mathrm{Co}_{3} \mathrm{O}_{4} / \mathrm{ZSM}-5$ after reaction, $3 \%$ $\mathrm{Co}_{3} \mathrm{O}_{4} / Z \mathrm{OSM}-5$ and $4 \% \mathrm{Co}_{3} \mathrm{O}_{4} / \mathrm{ZSM}-5$, which were presented by nitrogen adsorption-desorption isotherm. Accord-



Figure 11. $\mathrm{N}_{2}$ adsorption-desorption equilibrium curves



Figure 12. The pore dimension distribution (a)ZSM-5; (b) $1 \% \mathrm{Co}_{3} \mathrm{O}_{4} /$ ZSM-5; (c) $1 \% \mathrm{Co}_{3} \mathrm{O}_{4} / \mathrm{ZSM}-5$ after reaction; (d)) $3 \% \mathrm{Co}_{3} \mathrm{O}_{4} / \mathrm{ZSM}-5$; (e) $) 4 \% \mathrm{Co}_{3} \mathrm{O}_{4} / \mathrm{ZSM}-5$ ing to the classification of IUPAC and the characteristics of curves in Figure 11, the isotherms of both curve exhibited type-IV isotherm with the $\mathrm{H} 3$ hysteresis type of loop, which indicates that it is monolayer saturated adsorption. What is more, the material has a slit structure and uneven interior, and the loading of active components was composed of lamellar particles. By comparing the shape characteristics of the five curves in the figure, it can be determined that the pore structure of the catalyst has not changed significantly before and after the loading and reaction, indicating that the internal structure of ZSM-5 was relatively stable.

The pore size distribution was analyzed by the $\mathrm{BJH}$ model. Combined with the comprehensive analysis of Figure 12 and Table 3 above, it was found that a decrease in specific surface area as well as pore volume by impregnation of $\mathrm{Co}_{3} \mathrm{O}_{4}$ might be owing to the occupation of the pores of ZSM- 5 by active metals. Through the diffusion of the carrier, $\mathrm{Co}^{2+}$ diffused to the active site of the catalyst, partially replacing $\mathrm{Al}^{3+}$ in the $\mathrm{ZSM}-5$ skeleton, as the ionic radius of $\mathrm{Co}^{2+}$ is larger than that of $\mathrm{Al}^{3+} .{ }^{25}$ Compared with catalysts $\mathrm{b}$ and $\mathrm{c}$ before and after catalytic dehydrogenation, due to the formation of $\mathrm{H}_{2} \mathrm{O}$ and the loose active components on the surface of the catalyst resulted in the decrease of pore diameter and increase of specific surface area after the reaction.

\section{5. Catalytic Performance at different temperature of $\mathrm{Co}_{3} \mathrm{O}_{4}$}



Figure13. The overall conversion rate of $\mathrm{Co}_{3} \mathrm{O}_{4}$

Table3. The pore size and surface area distribution of ZSM-5, $\mathrm{Co}_{3} \mathrm{O}_{4} / Z S M-5$ and $\mathrm{Co}_{3} \mathrm{O}_{4} / Z S M-5$ after reaction

\begin{tabular}{lccc}
\hline Sample & Surface Area $/ \mathbf{m}_{\mathbf{2}} \cdot \mathbf{g}^{\mathbf{- 1}}$ & Pore Volume $/ \mathbf{c c} \cdot \mathbf{g}^{\mathbf{- 1}}$ & Pore Diameter/nm \\
\hline $\mathrm{ZSM}-5$ & 362.648 & 0.035 & 3.83 \\
$1 \% \mathrm{Co}_{3} \mathrm{O}_{4} / \mathrm{ZSM}-5$ & 319.814 & 0.033 & 3.816 \\
$1 \% \mathrm{Co}_{3} \mathrm{O}_{4} / \mathrm{ZSM}-5$ after reaction & 322.807 & 0.03 & 3.819 \\
$3 \% \mathrm{Co}_{3} \mathrm{O}_{4} / \mathrm{ZSM}-5$ & 303.363 & 0.031 & 3.817 \\
$4 \% \mathrm{Co}_{3} \mathrm{O}_{4} / \mathrm{ZSM}-5$ & 283.703 & 0.035 & 3.053 \\
\hline
\end{tabular}






Figure 14. The average conversion rate of $\mathrm{Co}_{3} \mathrm{O}_{4}$



Figure 15. The average selectivity of $\mathrm{Co}_{3} \mathrm{O}_{4}$

Combining with Figure13 and 14, it can be observed that the hydrogen conversion increased with increasing temperature. Especially it increased up to surpass $99 \%$ with relative stability when the reaction temperature enhanced above $130^{\circ} \mathrm{C}$. The overall conversion rate dropped with the time developed as presented in figure 13, which suggested that the performance of catalytic dehydrogenation reaction decreased gradually. Cobalt chloride was formed in the reaction by analysis of XRD. Consequently, it is the reason taht the formation of cobalt chloride, hydrogen chloride and water has damaged the catalyst including reducing the surface area and weakening the activity of catalyst. On the one hand, the water vapor reacts with the active components on the surface of the catalyst to form other components, reducing the oxygen activity level on the surface and thus reducing the activity of the catalyst. On the other hand, $\mathrm{Co}_{3} \mathrm{O}_{4}$ was partially inactivated after being chlorinated to cobalt chloride, and the deactivation of catalyst was accelerated by the formation of hydrochloric acid solution from hydrogen chloride gas and water. ${ }^{26,27}$ Nevertheless, the total conversion rate of hydrogen increased with the rise of temperature and the catalyst of $\mathrm{Co}_{3} \mathrm{O}_{4}$ had good stability.

As demonstrated in figure 15, the selectivity of hydrogen and chlorine reactions was obviously higher than that of hydrogen and oxygen reactions at different reaction temperatures. With the rise of temperature, the selectivity of hydrogen-chlorine reaction decreased gradually, while the selectivity of hydrogen-oxygen reaction increased generally. To sum up, the optimal reaction temperature for chlorine removal of hydrogen from tail was $130^{\circ} \mathrm{C}$, which was more favorable for hydrogen and oxygen reactions.

\section{6. Catalytic Performance of $\mathrm{Co}_{3} \mathrm{O}_{4} / \mathrm{ZSM}-5$}

\section{6. 1. Effect of Different Reaction Temperatures}

The catalytic performance of $\mathrm{Co}_{3} \mathrm{O}_{4} / Z \mathrm{ZSM}-5$ at different reaction temperature was acquired in Figure 16, which was loaded with $1 \%$ wt. and was calcined at $600{ }^{\circ} \mathrm{C}$. The average conversion rate of hydrogen removal catalyzed by catalyst increased first and then decreased with the rise of

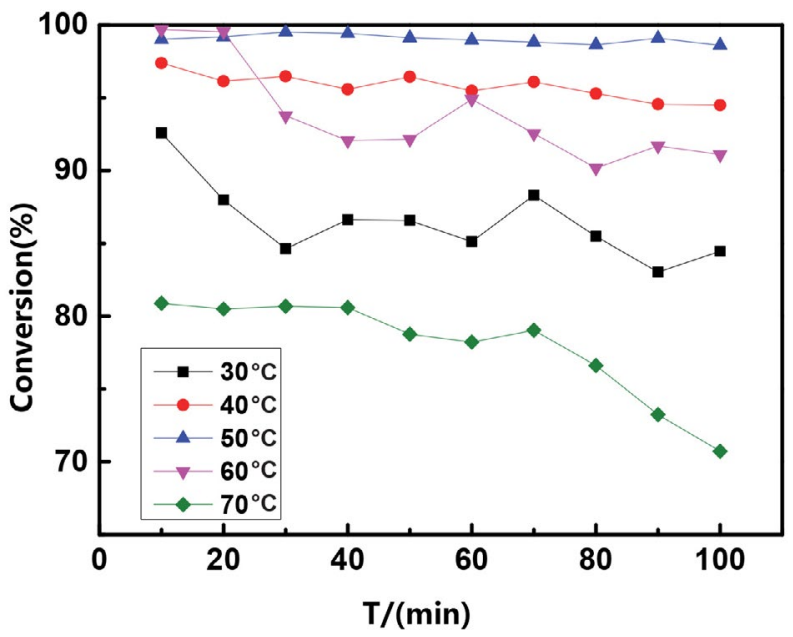

Figure 16. The overall conversion rate of $\mathrm{Co}_{3} \mathrm{O}_{4} / \mathrm{ZSM}-5$

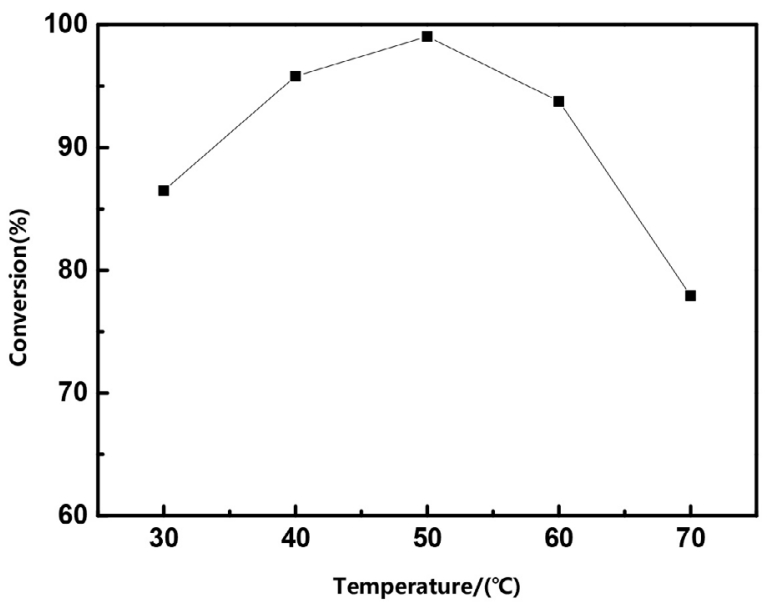

Figure 17. The average conversion rate of $\mathrm{Co}_{3} \mathrm{O}_{4} / \mathrm{ZSM}-5$ 


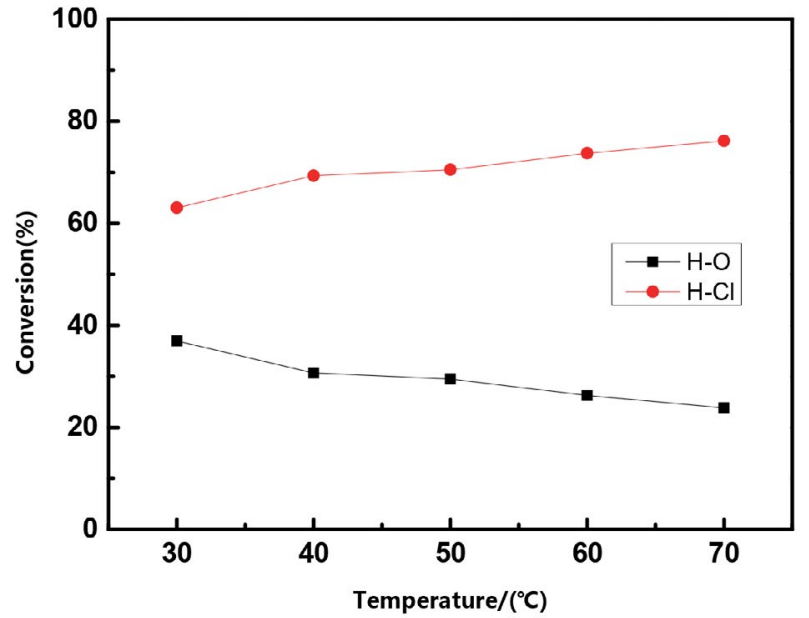

Figure 18. The average selectivity of $\mathrm{Co}_{3} \mathrm{O}_{4} / \mathrm{ZSM}-5$

temperature. Samples exhibited an average conversion rate of $99.04 \%$ at the reaction temperature of $50{ }^{\circ} \mathrm{C}$, which shows the enhanced catalytic performance. The reduction of hydrogen conversion rate demonstrated that hydrogen removal performance was gradually weakened as illustrated in Figure 16. This is because the formation hydrogen chloride and water has damaged the catalyst like reduced the surface area and weakened the activity of catalyst. It can been presented from the Figure 17 that the average hydrogen conversion first increased and then fell with the enhancement of temperature. First of all, the performance of catalytic dehydrogenation was obviously advanced from $30{ }^{\circ} \mathrm{C}$ to $50^{\circ} \mathrm{C}$ for the reason that the velocity of gas molecule increased with the enhancement of temperature. The corrosion of catalyst by chlorine gas was accelerated at surpass $50{ }^{\circ} \mathrm{C}$, resulting in unsatisfactory catalytic dehydrogenation of catalyst. Therefore, the optimum reaction temperature for the removal of hydrogen from tail chlorine catalyzed by $\mathrm{Co}_{3} \mathrm{O}_{4} / \mathrm{ZSM}-5$ catalyst is $50^{\circ} \mathrm{C}$.

As suggested by figure 18 , the selectivity of hydrogen and chlorine reactions was obviously higher than that of hydrogen and oxygen reactions at different reaction temperatures. With the rise of temperature, the selectivity of hydrogen-chlorine reaction increased gradually, while the selectivity of hydrogen-oxygen reaction decreased generally. To sum up, the optimal reaction temperature for chlorine removal of hydrogen from tail was $50{ }^{\circ} \mathrm{C}$, which was more favorable for hydrogen and chlorine reactions.

\section{6. 2. Effect of Different Calcination Temperature}

The catalytic performance of $\mathrm{Co}_{3} \mathrm{O}_{4} / \mathrm{ZSM}-5$ at different calcination temperature was set as Figure 19, which are loaded with $1 \% \mathrm{wt}$. and participated in reaction at $50{ }^{\circ} \mathrm{C}$. It can be obviously seen that the best performance for catalyzing the dehydrogenation was obtained under the calcination temperature of $500{ }^{\circ} \mathrm{C}$, with the average conversion

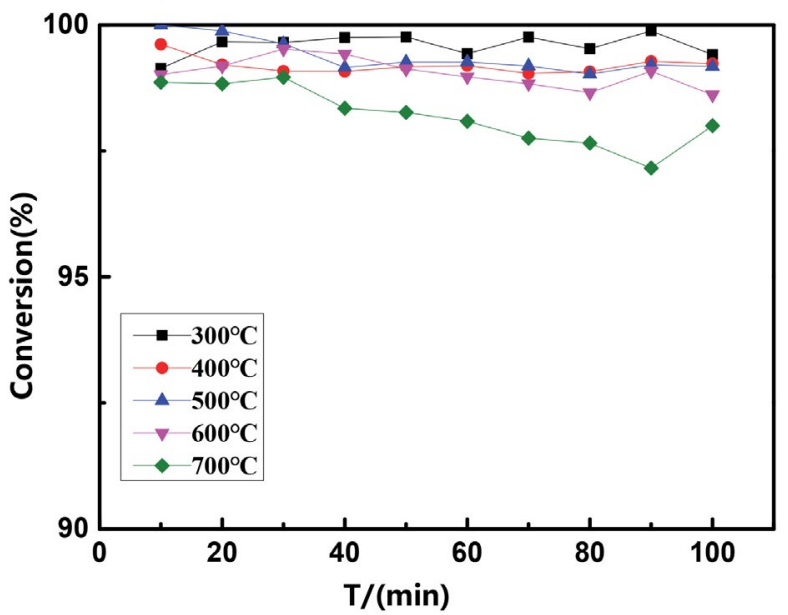

Figure 19. The overall conversion of $\mathrm{Co}_{3} \mathrm{O}_{4} / \mathrm{ZSM}-5$

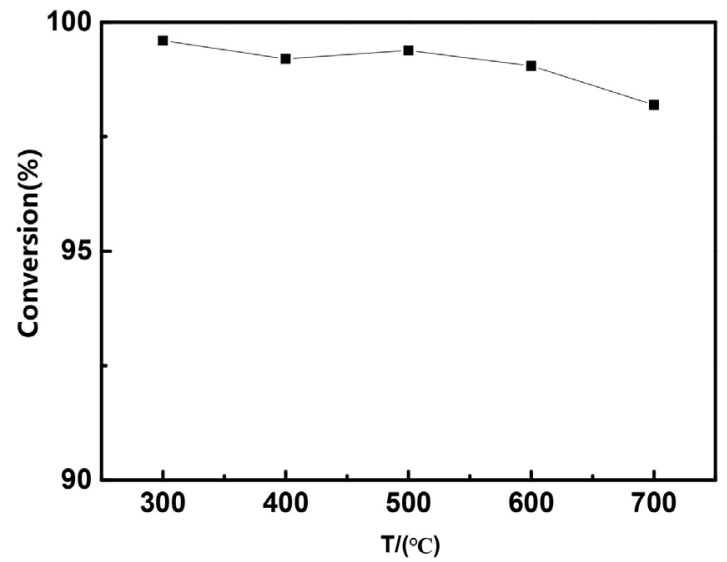

Figure 20. The average conversion of $\mathrm{Co}_{3} \mathrm{O}_{4} / \mathrm{ZSM}-5$

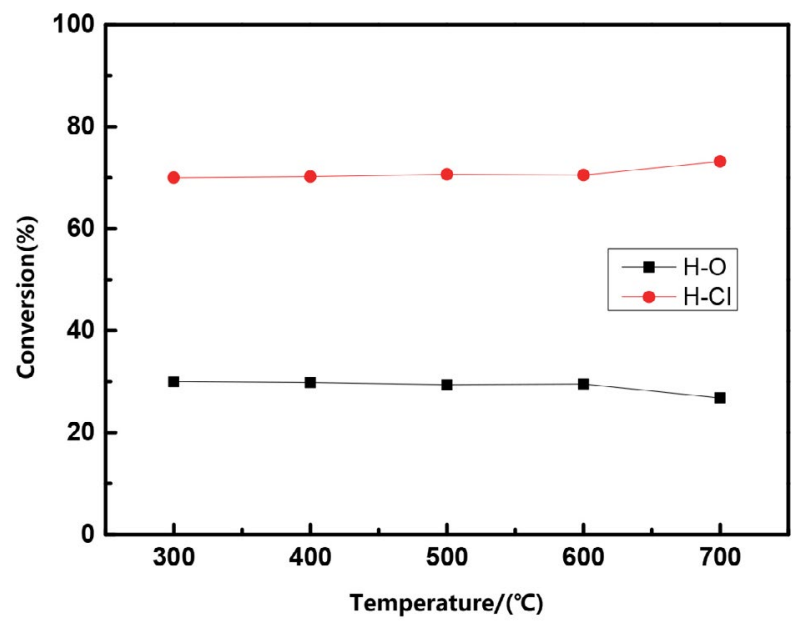

Figure 21. The average selectivity of $\mathrm{Co}_{3} \mathrm{O}_{4} / \mathrm{ZSM}-5$

rate of $\mathrm{Co}_{3} \mathrm{O}_{4} / Z \mathrm{ZSM}-5$ reached to $99.59 \%$. It can be revealed that hydrogen removal performance was gradually weakened with increasing of calcination temperature. Combined with the analysis of XRD, the optimum calci- 
nation temperature of the catalytic dehydrogenation is $300{ }^{\circ} \mathrm{C}$.

Can see clearly from Figure 21, selectivity of hydrogen chloride reaction were higher than that of hydrogen and oxygen reaction selectivity under different calcination temperature. With the increase of calcination temperature, hydrogen and chloride reaction selectivity was slightly elevated, while hydrogen and oxygen reaction selectivity was reduced somewhat, which is more inclined to the reaction of hydrogen and chlorine.

\section{6. 3. Effect of Loading Amounts on Catalytic Performance}

The catalytic performance of $\mathrm{Co}_{3} \mathrm{O}_{4} / \mathrm{ZSM}-5$ at loading amount was illustrated in Figure 22, which was calcined at $600{ }^{\circ} \mathrm{C}$ and participated in reaction at $50^{\circ} \mathrm{C}$. Next, the loading amount of $\mathrm{Co}_{3} \mathrm{O}_{4} / \mathrm{ZSM}-5$ was investigated in the catalytic dehydrogenation reaction as shown in the fig-

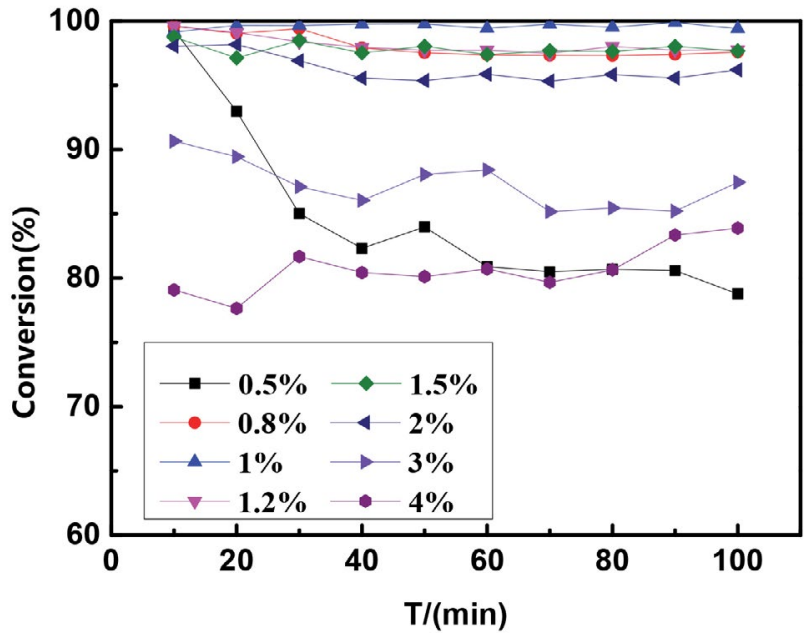

Figure 22. The overall conversion of $\mathrm{Co}_{3} \mathrm{O}_{4} / \mathrm{ZSM}-5$



Figure 23. The average conversion of $\mathrm{Co}_{3} \mathrm{O}_{4} / \mathrm{ZSM}-5$



Figure 24. The average selectivity of $\mathrm{Co}_{3} \mathrm{O}_{4} / \mathrm{ZSM}-5$

ure. It can be seen obviously that the change of average hydrogen conversion rate can be divided into four stages. First of all, the average conversion of hydrogen advanced dramatically with the load amount less than $0.8 \%$. And then the average conversion of hydrogen slowed down as the load increased from $0.8 \%$ to $1 \%$. After that, when the loading of $\mathrm{Co}_{3} \mathrm{O}_{4}$ is between $1 \%$ and $2 \%$, the conversion of hydrogen began to decline tardily. Finally, the conversion of hydrogen fell rapidly with the loading amount of cobaltosic oxide exceeding $2 \%$. It is the reason that the amount of catalyst loading corresponds to the active component. Less active components with lower loading, leading to poor catalytic performance of the catalyst. So catalytic activity increased greatly with the increase of the $\mathrm{Co}_{3} \mathrm{O}_{4}$ loading of the ZSM-5 catalyst. Afterwards, excessive loading will not bring about good results, which blocked the pores and holes of the carrier and reduced the reaction surface area, the catalytic effect of the catalyst decreased rapidly. Based on analysis of the experimental data, the active components were evenly dispersed on the surface of the carrier and the catalytic activity was the highest when the average hydrogen conversion rate reached $99.60 \%$ with the loading amount of $1 \%$.

As presented in figure 24, with elevating loading of catalyst, the selectivity of hydrogen-oxygen reaction and hydrogen chloride reaction was not observed the significant change, indicating that loading has little impact on the selectivity of hydrogen.

\section{7. Activity Test}

In this experiment, $\mathrm{Co}_{3} \mathrm{O}_{4} / \mathrm{ZSM}-5$ was used as catalyst, which was loaded with $1 \%$ wt. and calcined at $300{ }^{\circ} \mathrm{C}$. and reacted continuously for 540 minutes at $50^{\circ} \mathrm{C}$, with a sampling interval of 30 minutes each time.

From Figure 25, it can be seen that the catalytic dehydrogenation effect was relatively stable during the reaction time of 120 minutes, which total conversion rate of 


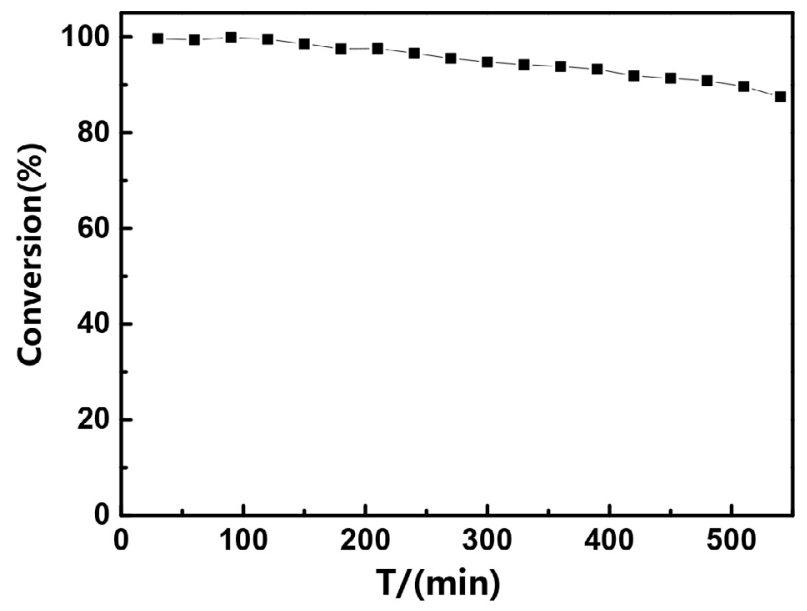

Figure 25. Total conversion rate of hydrogen in the catalytic reaction of $\mathrm{Co}_{3} \mathrm{O}_{4} / \mathrm{ZSM}-5$ over time

hydrogen in the catalytic reaction of $\mathrm{Co}_{3} \mathrm{O}_{4} / \mathrm{ZSM}-5$ achieved above $99 \%$. After that, the catalytic activity decreased gradually. After the reaction time of 540 minutes, total conversion rate of hydrogen only dropped at $88.48 \%$, meaning that excellent catalytic stability was significantly exhibited. The excellent catalytic activity of $\mathrm{Co}_{3} \mathrm{O}_{4} / Z S M-5$ catalysts can be attributed to the easy reducibility of $\mathrm{Co}^{3+}$, higher $\mathrm{Co}^{3+}$ content, higher surface content of lattice oxygen, and fast migration of oxygen ions in the lattice of cobaltosic oxide. ${ }^{28}$

\section{Conclusion}

Combined with the performance characterization analysis and experimental data of hydrogen removal catalyst, we can see that $\mathrm{Co}_{3} \mathrm{O}_{4} / \mathrm{ZSM}-5$ catalyst not only dropped the reaction temperature but also exhibited excellent catalytic performance than $\mathrm{Co}_{3} \mathrm{O}_{4}$. The analysis of XRD characterization and SEM images illustrated that $\mathrm{Co}_{3} \mathrm{O}_{4}$ catalyst produced small amounts of cobalt chloride. After the reaction, the catalyst agglomerated and the surface became rough, which reduced the surface area of the catalytic reaction and the active center involved in the reaction, leading to the gradual decrease of catalytic performance. However, the morphology of supported catalyst $\mathrm{Co}_{3} \mathrm{O}_{4} / \mathrm{ZSM}-5$ remained basically unchanged before and after the reaction, and its excellent catalytic activity can be attributed to the easy reducibility of $\mathrm{Co}^{3+}$, higher $\mathrm{Co}^{3+}$ content, higher surface content of lattice oxygen, and fast migration of oxygen ions in the lattice of cobaltosic oxide.

By comparing the catalytic dehydrogenation effect of $\mathrm{Co}_{3} \mathrm{O}_{4}$ at different reaction temperatures, the optimum temperature of $130^{\circ} \mathrm{C}$ showed the best stability. The preparation method was observed to influence the catalytic performance of the $\mathrm{Co}_{3} \mathrm{O}_{4} / \mathrm{ZSM}-5$ catalysts. We also find the optimal reaction condition is $1 \%$ wt. $\mathrm{Co}_{3} \mathrm{O}_{4}$ loads on $\mathrm{Co}_{3} \mathrm{O}_{4} / Z \mathrm{ZSM}-5$ catalyst with the calcination temperature of $300^{\circ} \mathrm{C}$ under the reaction temperature of $50^{\circ} \mathrm{C}$.Its average hydrogen conversion rate catalyzed within 110 minutes of reaction was $99.59 \%$, and only decreased to $88.48 \%$ after 540 minutes, which still showed certain catalytic activity. The $\mathrm{N}_{2}$ adsorption and desorption characterization showed that the part of pore structure of the catalyst might be blocked and the active components were separated from the surface of the carrier, which was consistent with the reduction of catalytic performance of the catalyst in the experiment.

Cobaltosic oxide is a kind of catalytic active component in catalytic dehydrogenation. Through the analysis of the selectivity of $\mathrm{Co}_{3} \mathrm{O}_{4}$ and $\mathrm{Co}_{3} \mathrm{O}_{4} / \mathrm{ZSM}-5$, the selectivity of hydrogen and chlorine reaction is greater than the selectivity of hydrogen and oxygen. It could be confirmed that $\mathrm{Co}_{3} \mathrm{O}_{4}$ is more advantageous to catalyze the reaction of hydrogen and chlorine.

\section{Acknowledgement}

The authors thank the National Natural Science Foundation of China (No. 50972097) and the Natural Science Foundation of Shanxi (No.2008011025) for supporting this work.

\section{Conflict of Interest}

The authors declare no conflict of interest

\section{Reference}

1. H. Khasawneh, M. N. Saidan, M. Al-Addous, Energy Explor. Exploit. 2019, 37, 1053-1072.

DOI:10.1177/0144598719839767

2. J. I. Otashu, M. Baldea, Comput. Chem. Eng. 2019, 121, 396408. DOI:10.1016/j.compchemeng.2018.08.030

3. D. H. Wang, W. Z. Pan, China Chlor-Alkali. 2017,7,1-5. DOI: 10.3969/j.issn.1009-1785.2017.07.001

4. Y. Luo, China Chlor-Alkali. 2017,1,1-3.

5. P. C. Zhang, China Chlor-Alkali. 2019, 2, 1-3. DOI:10.3969/j.issn.1009-1785.2019.02.001

6. S. Peantong, S. Tangjitsitcharoen, IOP Conference Series: Materials Science and Engineering. 2017, 215, 012018.

DOI:10.1088/1757-899X/215/1/012018

7. J. P. Zhang, D. S. Li, Y. Z. Chen, Environ. Prot. 2004, 12, $22-24$. DOI:10.3969/j.issn.0253-9705.2004.12.005

8. K. T. Chue, J. N. Kim, Y. J. Yoo, S. H. Cho, R. T. Yang, Ind. Eng. Chem. Res. 1995,34, 591-598. DOI:10.1021/ie00041a020

9. K. Kato,M. kawaguchi, Method and apparatus for purifying polluted soil,and apparatus for emitting chlorine-containing gas and apparatus for decomposing polluted gas using the same, US Patent Number 20000741332, date of parent January 24, 2002.

10. G. J. Kulcsar, M. Kulcsar-Novakova, Stud. Cercet. Chim. 1957, $8,221-230$. 
11. G. C. Allen, G. P. Butt, Removal of hydrogen from chlorine, GB Patent Number 1388292, date of parent March 26, 1975.

12. H. Coolen, Catalytic removal of hydrogen from chlorine, ZA Patent Number 6804493, date of parent January 12, 1970.

13. W. J. M. Pieters, F. Wenger, Removal of low concentrations of hydrogen from chlorine gas, US Patent Number 4224293, date of parent September 23, 1980.

14. H. L. Zhou, Study on Catalytic Dehydrogenation Performance of Hydrophobic Catalyst and Piatinum Metal Catalyst in the Tail Chlorine at Low Temperature.Dissertation. Taiyuan:Taiyuan University of Technology, 2015.

15. T. T. Lu, Research on Catalytic Dehydrogenation Performance of $\mathrm{Au}$ and $\mathrm{Au}-\mathrm{Ag}$ Double Metals Supported on $\mathrm{Al}_{2} \mathrm{O}_{3}$ in Tail Chlorine at Low Temperature. Dissertation. Taiyuan:Taiyuan University of Technology, 2016.

16. H. H. Wang, T. T. Lu, Y. N. Li, B. Wu, J. W. Xue, F. X. Li, Z. P. Lv, J. Chemistry. 2016, 2090-9063. DOI:10.1155/2016/5620316

17. X. Q. Chen, Study on Performance of Dehydrogen Removal from Tail Chlorine Catalyzed by Copper and Copper Oxide Catalysts at Low Temperature. Dissertation. Taiyuan:Taiyuan University of Technology, 2018.

18. X. Liu, L, Xue, X. Q. Chen, J. S. Liu, H. H. Wamg, J. W. Xue, F. X. Li, Z. P. Lv, Quim. Nova 2019, 42, 319-328.

DOI:10.21577/0100-4042.20170322
19. T. Kanazawa, Appl. Catal., B 2006, 65, 185-190. DOI:10.1016/j.apcatb.2006.01.001

20. B. Zhang, X. B. Zhang, L. Y. Xu, Y. J. Zhang, Y. H. Qin, C. F. Liang, React. Kinet., Mech. Catal. 2013,110, 207-214. DOI:10.1007/s11144-013-0589-7

21. S. J. Luo, Chlor-Alkali Ind. 1991, 2, 23-25.

22. G. K. Liu, F. J. Lin, Chlor-Alkali Ind. 2006, 3, 24-26. DOI:10.3969/j.issn.1008-133X.2006.03.009

23. X. T. Zhang, Y. Yan, R. Soc, Open Sci. 2018, 5, 8. DOI:10.1098/rsos.180587

24. G. S. Qi, R. T. Yang, Appl. Catal., A 2005, 287, 25-33. DOI:10.1016/j.apcata.2005.03.006

25. X. W. Zou, J. Z. Yao, X. M. Yang, W. L. Song, W. G. Lin, Chin. J. Process Eng. 2007,6,1107-1113.

DOI:10.1016/S1001-6058(07)60030-4

26. D. L. Mowery, M. S. Graboski, T. R. Ohno, R. L. McCormick, Appl. Catal., B 1999, 21, 157-169.

DOI:10.1016/S0926-3373(99)00017-X

27. D. N. Gao, S. Wang, C. X. Zhang, Z. S. Yuan, S. D. Wang, Chin. J. Catal. 2008, 29, 1221-1225.

DOI:10.1016/S1872-2067(09)60027-9

28. Z. Z. Zhu, G. Z. Lu, Z. G. Zhang, Y. Guo, Y. L. Guo, Y. Q. Wang, ACS Catal. 2013, 3, 1154-1164.

DOI: $10.1021 / \operatorname{cs} 400068 \mathrm{v}$

\section{Povzetek}

$\mathrm{Co}_{3} \mathrm{O}_{4} / \mathrm{ZSM}-5$ je bil uporabljen za dehidrogenacijo rezidualne klorove plinske mešanice iz klor-alkalne industrije zaradi svoje nizke cene in varnosti. $\mathrm{Co}_{3} \mathrm{O}_{4} / Z \mathrm{ZSM}-5$ je bil sintetiziran z volumsko impregnacijsko metodo. Dehidrogenacijske lastnosti $\mathrm{Co}_{3} \mathrm{O}_{4} / \mathrm{ZSM}-5$ smo preučili s katalitično reakcijo vodika s kisikom in klorom, ki je bila izvedena v strnjenem sloju, pri čemer je bila mešanica plinov pripravljena skladno s sestavo in vsebnostjo klorove plinske mešanice $\mathrm{v}$ industriji: $\mathrm{Cl}_{2}(65 \%-80 \%), \mathrm{N}_{2}(6-16 \%), \mathrm{O}_{2}(8 \%-10 \%)$ in $\mathrm{H}_{2}(1.5 \%-4 \%)$. Katalitična učinkovitost in $\mathrm{Co}_{3} \mathrm{O}_{4} / \mathrm{ZSM}-5$ stabilnost pri dehidrogenaciji klorove plinske mešanice je bila boljša kot pri čistem $\mathrm{Co}_{3} \mathrm{O}_{4}$. Po kalcinaciji na $300{ }^{\circ} \mathrm{C} \mathrm{je} \mathrm{Co}_{3} \mathrm{O}_{4} / \mathrm{ZSM}_{-} 5 \mathrm{z}$ 1 ut.\% vsebnostjo $\mathrm{Co}_{3} \mathrm{O}_{4}$ izkazal pri $50{ }^{\circ} \mathrm{C}$ odlične katalitične lastnosti s povprečno konverzijo vodika do $99.95 \%$.

Except when otherwise noted, articles in this journal are published under the terms and conditions of the Creative Commons Attribution 4.0 International License 
